\title{
Student's Perspective on the Competency of Internet of Thing-Based Lecturers as a Basic Skill in the Era of Industrial Revolution 4.0
}

\author{
Annur Fitri Hayati ${ }^{* *}$, Jean Elikal Marna ${ }^{2}$ \\ 1,2Universitas Negeri Padang, Padang, Indonesia \\ "Corresponding author. Email. annurfitrihayati@gmail.com
}

\begin{abstract}
The era of the industrial revolution 4.0 is currently needed to produce competitive human resources. Higher education is the highest institution that produces the most workforce, so universities must increase the capacity and capability of their lecturers. Educational competencies are competencies related to learning activities, in today's technological era educational competencies are based more on internet-based learning as basic skills. Graduates will not be able to compete well if lecturers do not have competencies that match the needs of the industrial revolution era 4.0. Based on this, the purpose of this study is to analyze student perspectives on internet-based competencies as basic skills in the education era 4.0 in the field of education at Univeristas Negeri Padang. The research sample was 350 students of the Faculty of Economics, State University of Padang. The data analysis technique used is descriptive analysis. The results of research from 7 internet-based lecturer competence indicators obtained an average TCR of 84.01 with the very good category.
\end{abstract}

Keywords: Lecturer competencies, Internet of thing, Revolusi industry 4.0.

\section{INTRODUCTION}

The Industrial Revolution 4.0 was launched at Davos Switzelan, where the presence of the digital era presents challenges in education. In this era, the world of education is required to have output in the form of quality human resources so that they are able to compete with the output of developed countries. Because globalization must not be avoided but must be faced with full preparation.

According to the market research institute eMarketer, the country's netter population reached 83.7 million people in 2014 and reached 123 million people in 2018. This makes Indonesia one of the top 6 countries with the largest number of internet users in the world.

Research conducted by the leading educational organization Cambridge International part of the University of Cambridge in the UK found Indonesian students use technology in classrooms more than many other countries, often outperforming more developed countries. In addition, more than two-thirds of Indonesian students $76 \%$ use smart phones in class and
$81 \%$ even use them to do homework (BBC News Indonesia).

From the results of internet user data and the results of the above research, we can conclude that currently Indonesian education is technology-based. However, one of the efforts to improve the quality of Indonesian human resources in order to be able to face the Industrial Revolution 4.0 is determined by the quality of the teaching staff, lecturers and other teaching staff. So that educators must be able to master expertise, ability to adapt to new technologies and global challenges.

According to Tosepu, there are 4 qualifications and competencies of lecturers needed in the era of Education 4.0, namely: (1) Educational competence, internet of things-based educational competence as basic skills in this era; (2) Competence for technological commercialization, having the competence to bring students to have an entrepreneurial attitude with technology on the results of students' innovative work; (3) Competence in 
globalization, a world without borders, not stuttering towards various cultures, hybrid competence, namely global competence and excellence in solving national problems; (4) Competence in future strategies, the world is easy to change and runs fast, so that you have the competence to predict exactly what will happen in the future and its strategies by means of joint-lectures, joint-research, joint-resources, staff mobility and rotation, understanding SDG's direction and so on [1]

Table 1. Rank of Number of Internet Users 2013-2018

\begin{tabular}{|l|l|c|c|c|c|c|c|}
\hline \multicolumn{2}{|l|}{} & $\mathbf{2 0 1 3}$ & $\mathbf{2 0 1 4}$ & $\mathbf{2 0 1 5}$ & $\mathbf{2 0 1 6}$ & $\mathbf{2 0 1 7}$ & $\mathbf{2 0 1 8}$ \\
\hline 1 & China & 620,7 & 643,6 & 669,8 & 700,1 & 736,2 & 777,0 \\
\hline 2 & US** & 246,0 & 252,9 & 259,3 & 264,9 & 269,7 & 274,1 \\
\hline 3 & India & 167,2 & 215,6 & 252,3 & 283,8 & 313,8 & 346,3 \\
\hline 4 & Brazil & 99,2 & 107,7 & 113,7 & 119,8 & 123,3 & 125,9 \\
\hline 5 & Japan & 100,0 & 102,1 & 103,6 & 104,5 & 105,0 & 105,4 \\
\hline 6 & Indonesia & 72,8 & 83,7 & 93,4 & 102,8 & 112,6 & 123,0 \\
\hline 7 & Rusia & 77,5 & 82,9 & 87,3 & 91,4 & 94,3 & 96,6 \\
\hline 8 & Germany & 59,5 & 61,6 & 62,2 & 62,5 & 62,7 & 62,7 \\
\hline 9 & Mexico & 53,1 & 59,4 & 65,1 & 70,7 & 75,7 & 80,4 \\
\hline 10 & Nigeria & 51,8 & 57,7 & 63,2 & 69,1 & 76,2 & 84,3 \\
\hline 11 & UK** & 48,8 & 50,1 & 51,3 & 52,4 & 53,4 & 54,3 \\
\hline 12 & France & 48,8 & 49,7 & 50,5 & 51,2 & 51,9 & 52,5 \\
\hline 13 & Philippines & 42,3 & 48,0 & 53,7 & 59,1 & 64,5 & 69,3 \\
\hline 14 & Turkey & 36,6 & 41,0 & 44,7 & 47,7 & 50,7 & 53,5 \\
\hline 15 & Vietnam & 36,6 & 40,5 & 44,4 & 48,2 & 52,1 & 55,8 \\
\hline 16 & South Korea & 40,1 & 40,4 & 40,6 & 40,7 & 40,9 & 41,0 \\
\hline 17 & Egypt & 34,1 & 36,0 & 38,3 & 40,9 & 43,9 & 47,4 \\
\hline 18 & Italy & 34,5 & 35,8 & 36,2 & 37,2 & 37,5 & 37,7 \\
\hline 19 & Spain & 30,5 & 31,6 & 32,3 & 33,0 & 33,5 & 33,9 \\
\hline 20 & Canada & 27,7 & 28,3 & 28,8 & 29,4 & 29,9 & 30,4 \\
\hline 21 & Argentina & 25,0 & 27,1 & 29,0 & 29,8 & 30,5 & 31,1 \\
\hline 22 & Colombia & 24,2 & 26,5 & 28,6 & 29,4 & 30,5 & 31,3 \\
\hline 23 & Thailand & 22,7 & 24,3 & 26,0 & 27,6 & 29,1 & 30,6 \\
\hline 24 & Poland & 22,6 & 22,9 & 23,3 & 23,7 & 24,0 & 24,3 \\
\hline 25 & South Africa & 20,1 & 22,7 & 25,0 & 27,2 & 29,2 & 30,9 \\
\hline WorldWide*** & $\mathbf{2 . 6 9 2 , 9}$ & $\mathbf{2 . 8 9 2 , 7}$ & $\mathbf{3 . 0 7 2 , 6}$ & $\mathbf{3 . 2 4 6 , 3}$ & $\mathbf{3 . 4 1 9 , 9}$ & $\mathbf{3 . 6 0 0 , 2}$ \\
\hline
\end{tabular}

According to Tosepu, there are 4 qualifications and competencies of lecturers needed in the era of Education 4.0, namely: (1) Educational competence, internet of things-based educational competence as basic skills in this era; (2) Competence for technological commercialization, having the competence to bring students to have an entrepreneurial attitude with technology on the results of students' innovative work; (3) Competence in globalization, a world without borders, not stuttering towards various cultures, hybrid competence, namely global competence and excellence in solving national problems; (4) Competence in future strategies, the world is easy to change and runs fast, so that you have the competence to predict exactly what will happen in the future and its strategies by means of joint-lectures, joint-research, joint-resources, staff mobility and rotation, understanding SDG's direction and so on [1].

Lecturer competence is a set of knowledge, skills and behaviors that must be possessed, internalized and mastered by lecturers in carrying out their professional duties [2]. The provisions of the Ministry of Research, Technology and Higher Education, a competent lecturer must have four competencies, namely pedagogic, professional, personality and social. The parameter used to measure the competence of lecturers in this study is the student perspective. Students are chosen because students are direct consumers who experience the teaching services provided by a lecturer. Mashudi (2014) proved that there is a positive relationship between perceptions of 
lecturers' professional competence and student learning motivation. Other research conducted by Istikoma (2015) also proved that there was a significant positive effect on student attitudes towards lecturer competence in teaching on learning achievement.

It can be concluded that student perspectives regarding lecturer competence are important to study, because in the digital era with shifting abilities and habits of students as digital native, it is expected that the competence of lecturers will also shift to internetbased competencies so that they can accommodate student needs and simplify the learning process in class.

\subsection{Lecturer Competence}

In the Republic of Indonesia Law No. 14/2005 concerning teachers and lecturers, the definition of "lecturers are professional educators and scientists with the main task of transforming, developing and disseminating science, technology and arts through education, research and community service" [3].

In the advancement of higher education, lecturers have a very high role, we can see this in the functions and objectives of higher education, namely implementing the tridarma of higher education (education, research and community service) in which these tasks must be carried out by lecturers in a professional manner. With the presence of qualified lecturers, it will affect the progress of the Higher Education.

Sukahar said that lecturers are a determining factor in efforts to improve the quality of Higher Education, the strategic action by improving the quality of lecturers is not only quality in the formal sense but also must pay attention to how lecturers provide lectures.

Lecturer / teacher competence is the ability of a teacher to carry out his / her duties responsibly and appropriately [4]. Meanwhile, Uwess said that there are three main aspects that every lecturer from any field of study must have, namely teaching plans, teaching procedures and interpersonal relationships.

The competence of lecturers in the Republic of Indonesia Law No.14 of 2005 concerning teachers and lecturers in article 2 is meant that lecturer competence is a set of knowledge, skills and behavior in carrying out professional tasks. The lecturers' competences as referred to in paragraph 1 include pedagogical, personal, professional and social competences.
In the Educator Certification Guidelines for Lecturers issued by the Directorate General of Higher Education, Ministry of Education and Culture 2012, there are four competencies of lecturers as an aspect of assessment, namely:

1. Pedagogic competence, namely the ability to design learning, the ability to carry out the learning process, the ability to assess the learning process and outcomes, and the ability to use research results to improve the quality of learning [5]

2. Professional competence, namely the ability to master learning materials broadly and deeply which allows them to guide students to meet the competency standards set out in educational standards [6]

3. Personality competence, namely the ability of a personality that is solid, stable, mature, wise and has good character, becomes an example for students and has noble character [6]

4. Social competence, namely the ability of educators as part of society to communicate and socialize effectively with students, fellow educators, education staff, parents / guardians of students and the surrounding community [6]

There are five competencies that lecturers must have in overcoming challenges in the industrial era 4.0 [7], namely:

1. Educational competence, internet-based competence of thing as a basic skill because of having knowledge in the field of internet of things, learning through digital human is easy to apply, such as implementing blended learning which will reduce paper usage and increase student ability in the teaching and learning process.

2. Competence in research, competence to build networks to grow knowledge, research direction and skills to get international grants, where by having this competence lecturers will be easy to assist students in applying global research.

3. Competence for technological commercialization, having the competence to bring groups and students to commercialization with technology based on the results of innovation and research, this will help lecturers to increase the entrepreneurial spirit of students where students will be able to use the internet to start their business without having to open a shop and rent it,

4. Competence in globalization, a world without borders that does not stutter towards various cultures with this competence the lecturer teaches 
students to get to know various cultures in the world, hybrid competence, namely global competence and the advantage of solving national problems

5. Strategic competence in the future, where the world is easy to change and runs fast so that it has the competence to predict exactly what will happen in the future and its strategy, by means of joint-lectures, joint-research, joint-publication, joint-ab, staff- mobility and rotation, understanding SDG's and industry and so on, here students are taught to see business opportunities from learning by seeing some of the successful entrepreneurs today who started from making new breakthroughs and what they sell is creativity.

\subsection{Student Perspective}

Perspective according to Suma Atmadja is a person's perspective or the way someone behaves towards a problem or event phenomenon [8]. Suhanadji defines perspective is the insight or perspective of a person in assessing problems that occur around him [9]. Meanwhile, perspective according to Gerungan is a process in which a person assesses and responds to what is happening in his environment and whether or not there is a relationship with him or not and according to the Big Indonesian Dictionary $(\mathrm{KBBI})$ perspective is a perspective.

From the expert's thoughts above, we can conclude that perspective is a person's perspective in assessing and responding to the phenomena that occur to him. Student perspectives on lecturer competence can be interpreted as a way of seeing students in assessing and responding to the ability of knowledge, skills and behaviors that lecturers have in the learning process.

\section{METHODS}

The data analysis technique in this study used a descriptive survey type of analysis. Based on Fraenkel, Wallen \& Hyun (2012), a descriptive survey is a non-experimental design that measures the characteristics of a sample at one point in time [10] The sample taken in this study was determined using the Slovin formula. A total population of 3224 , obtained a sample of 350 students from all departments at the Faculty of Economics, Universitas Negeri Padang, namely the Department of Economic Education, Economics, Management, Accounting and Diploma.

The sampling technique is needed to determine the number of students who will be the object of research or samples from each department. In this study, sampling using calculations based on Yatim Riyanto [11]. In this way the proportional characteristics of each level will be found in proportion to each population. In this study using a Likert scale with 5 category choices for the questioner, namely (1) never, (2) rare, (3) sometimes, (4) often, and (5) always.

\section{RESULT AND DISCUSSION}

\subsection{Ability to Design Lessons}

The ability to design learning can be seen from the syllabus / RPS prepared by the lecturer before lectures begin, where the syllabur / RPS contains learning material for one semester, the method to be used, the reading sources and the assessments to be used. Based on the results of research, the ability of UNP Faculty of Economics lecturers in designing learning can be seen in table 2 below.

Table 2. Ability to Design Learning

\begin{tabular}{|l|l|l|l|l|l|l|l|}
\hline & \multicolumn{1}{|c|}{ Statement } & SL & SR & KK & J & TP & TCR \\
\hline 1 & $\begin{array}{l}\text { Lecturers provide a lecture syllabus that can be } \\
\text { accessed online at the beginning of the lecture }\end{array}$ & 87,14 & 9,71 & 2,86 & 0,29 & 0 & 96,74 \\
\hline
\end{tabular}

Respondents stated that $87.14 \%$ of lecturers had planned learning well, this was evidenced by the lecture syllabus that had been very well prepared and uploaded on e-learning so that it could be accessed easily by students.

\subsection{Ability to Carry Out the Learning Process}

The ability of Lecturers to carry out the learning process now must always be related to the use of technology, this can be seen in the following table : 
Table 3. Ability to Carry Out the Learning Process

\begin{tabular}{|l|l|l|l|l|l|l|l|}
\hline & \multicolumn{1}{|c|}{ Statement } & SL & SR & KK & J & TP & TCR \\
\hline 2 & $\begin{array}{l}\text { Lecturers use learning media and technology during } \\
\text { class learning }\end{array}$ & 50,29 & 42,29 & 6,86 & 0,57 & 0,00 & 88,46 \\
\hline 3 & $\begin{array}{l}\text { Lecturers have no trouble using digital devices such as } \\
\text { laptops and infocus in the classroom }\end{array}$ & 48,29 & 28,86 & 9,43 & 7,43 & 6,00 & 81,20 \\
\hline 4 & $\begin{array}{l}\text { Lecturers in the classroom take advantage of online } \\
\text { attendance facilities }\end{array}$ & 54,00 & 31,43 & 13,14 & 1,43 & 0,00 & 87,60 \\
\hline 5 & $\begin{array}{l}\text { Lecturers provide lecture materials / materials that can } \\
\text { be accessed online }\end{array}$ & 39,43 & 46,00 & 14,00 & 0,57 & 0,00 & 84,86 \\
\hline 7 & $\begin{array}{l}\text { Lecturers provide examples that come from the } \\
\text { internet and are relevant to learning material }\end{array}$ & 24,00 & 46,57 & 25,43 & 3,14 & 0,86 & 77,94 \\
\hline 9 & $\begin{array}{l}\text { Prior to Covid-19, Lecturers applied online learning } \\
\text { through e-learning or other online applications }\end{array}$ & 36,29 & 0,00 & 56,00 & 7,14 & 0,57 & 72,86 \\
\hline 10 & $\begin{array}{l}\text { Lecturers conduct online lectures according to a } \\
\text { predetermined lecture schedule }\end{array}$ & 50,29 & 41,14 & 7,14 & 1,43 & 0,00 & 88,06 \\
\hline 17 & $\begin{array}{l}\text { Delivery of material and answers by lecturers during } \\
\text { online lectures is in accordance with the material }\end{array}$ & 44,00 & 43,43 & 10,29 & 1,71 & 0,57 & 85,71 \\
\hline & \begin{tabular}{l} 
Average \\
\hline
\end{tabular} & 43,32 & 34,96 & 17,79 & 2,93 & 1,00 & 83,34 \\
\hline
\end{tabular}

Overall the Lecturers' ability in carrying out the learning process is categorized as very good, especially in the use of technology in the classroom, more than $50 \%$ of lecturers have used technology in the learning process in the classroom. However, before online learning due to the Covid-19 outbreak, the e-learning facilities provided by the University had not been used optimally, only $36.29 \%$ of the Faculty of Economics lecturers used online learning facilities to support the learning process.

\subsection{Ability to Use Research Results to Improve Learning Quality}

The results of recent research conducted either by the lecturer themselves or the results of research by other academics both in terms of education and economics can be used to improve the quality of learning. The following table shows the ability of UNP Faculty of Economics lecturers to utilize the results of research to improve the quality of learning applied in online learning.

Table 4. Ability to Use Research Results to Improve Learning Quality

\begin{tabular}{|l|l|l|l|l|l|l|l|}
\hline & \multicolumn{1}{|c|}{ Statement } & SL & SR & KK & J & TP & TCR \\
\hline 15 & $\begin{array}{l}\text { Lecturers provide a new learning experience in every } \\
\text { online lecture }\end{array}$ & 61,43 & 19,14 & 16,00 & 2,86 & 0,57 & 87,6 \\
\hline
\end{tabular}

The results showed that more than half of the Faculty of Economics lecturers were able to provide new learning experiences by applying the latest Internet-based learning methods for students.

\subsection{Communication with Students}

Communication with students is very important, especially during online learning. Smooth communication will affect the learning process and also the personal relationship between lecturers and students. Table 5 below shows that the communication between lecturers and students as learners has gone well, but students think that in online lectures, Lecturers at the Faculty of Economics, UNP are not very motivating. 
Table 5. Communication with Students

\begin{tabular}{|l|l|l|l|l|l|l|l|}
\hline & \multicolumn{1}{|c|}{ Statement } & SL & SR & KK & J & TP & TCR \\
\hline 8 & $\begin{array}{l}\text { Lecturers give permission to students to consult } \\
\text { subject matters through online media, such as } \\
\text { WhatsApp and email or other online media }\end{array}$ & 33,71 & 39,71 & 18,29 & 6,57 & 1,71 & 79,43 \\
\hline 14 & $\begin{array}{l}\text { Lecturers provide motivation to students during online } \\
\text { lectures }\end{array}$ & 27,43 & 38,00 & 26,29 & 7,43 & 0,86 & 76,74 \\
\hline & Average & 30,57 & 38,86 & 22,29 & 7,00 & 1,29 & 78,09 \\
\hline
\end{tabular}

The results showed that lecturers at the Faculty of Economics, State University of Padang had used online facilities or applications to maintain communication with students. In line with Ety's research (2015) which states that the teaching situation or the teaching and learning interaction process can occur in various communication patterns, in the world of education the learning process will be effective, if communication and interaction between educators and students occurs intensively [12].

One of the strategies to carry out productive interactions with students is to assist the development of student achievement, by seeing learning as a social process, the main role of the teacher is as someone who helps develop students. The assistance provided by the teacher can take the form of (a) showing a model to show how something works; (b) show verbally and nonverbally a process or way of thinking of an expert or (c) break down tasks into small parts or reorganize complex assignments [13].

\subsection{Mastering Student Characteristics}

A lecturer must be able to understand the characteristics of students, this understanding can be generated by monitoring student behavior and monitoring student involvement. From table 6, the lecturers of the Faculty of Economics UNP have carried out this role well, it can be seen from the TCR score which is categorized as good.

From Mutaharoh et al observations, in terms of delivering material in class using the e-learning method, the lecturer can understand the character of students about opening their mindset to technological change [14]

Table 6. Mastering the Characteristics of Students

\begin{tabular}{|l|l|c|c|c|c|c|c|}
\hline \multicolumn{1}{|c|}{ Statement } & SL & SR & KK & J & TP & TCR \\
\hline 16 & $\begin{array}{l}\text { Lecturers monitor student attitudes and behavior } \\
\text { online }\end{array}$ & 26,57 & 45,43 & 21,43 & 6,00 & 0,57 & 78,29 \\
\hline 19 & $\begin{array}{l}\text { Lecturers monitor student involvement in online / } \\
\text { online lectures }\end{array}$ & 45,14 & 43,14 & 9,14 & 2,57 & 0,00 & 86,17 \\
\hline & Average & 35,86 & 44,29 & 15,29 & 4,29 & 0,29 & 82,23 \\
\hline
\end{tabular}

\subsection{Mastering Learning Theory and Principles of Educating Learning}

Online learning requires lecturers to be more creative and change the learning methods that are carried out face-to-face into learning methods that can be in accordance with online learning so that learning material can be conveyed properly.

The table above shows that the Lecturers of the Faculty of Economics UNP have mastered the learning theory and principles of educational learning in a good category. 
Table 7. Mastering Learning Theory and Principles of Educating Learning

\begin{tabular}{|l|l|c|c|c|c|c|c|}
\hline \multicolumn{1}{|c|}{ Statement } & SL & SR & KK & J & TP & TCR \\
\hline 20 & $\begin{array}{l}\text { Students are able to understand learning material that } \\
\text { is conveyed online }\end{array}$ & 18,00 & 34,86 & 35,71 & 10,00 & 1,43 & 71,60 \\
\hline 21 & $\begin{array}{l}\text { Lecturers respond to student questions regarding } \\
\text { learning material quickly in online lectures }\end{array}$ & 28,86 & 50,57 & 16,29 & 4,00 & 0,29 & 80,74 \\
\hline & \multicolumn{1}{|c|}{ Average } & 23,43 & 42,71 & 26,00 & 7,00 & 0,86 & 76,17 \\
\hline
\end{tabular}

\subsection{Ability to Assess Learning Process and Outcomes}

The learning process can be declared successful or not after an assessment by the lecturer, both in terms of the learning process itself and the assessment of learning outcomes to determine whether there has been a change in student understanding of something.

Table 8 below shows the extent to which the Faculty of Economics lecturers' ability to assess learning processes and outcomes from the student's perspective.

From the research results, it can be seen that the
Faculty of Economics lecturers are considered to have good abilities in assessing the learning process and outcomes. Lecturers have provided various forms of assignments using online applications or media, and have been able to provide feedback and assessment of learning outcomes by utilizing the use of online application learning. As for the efforts of the Universitas Negeri Padang so that lecturers can use e-learning and internet-based learning of things by conducting training, the method of implementation carried out in IoT training is training in the form of group work that is able to make training take place effectively and efficiently. [15]

Table 8. Ability to Assess Learning Process and Outcomes

\begin{tabular}{|c|c|c|c|c|c|c|c|}
\hline & Statement & SL & SR & $\overline{\mathrm{KK}}$ & $\bar{J}$ & TP & TCR \\
\hline 6 & $\begin{array}{l}\text { Lecturers Provide Quizzes by utilizing digital } \\
\text { platforms / applications such as e-learning, kahoot, } \\
\text { quizizz, etc. }\end{array}$ & 20,29 & 45,43 & 28,29 & 5,14 & 0,86 & 75,83 \\
\hline 11 & $\begin{array}{l}\text { Lecturers give assignments using online media such as } \\
\text { e-learning and other applications }\end{array}$ & 55,71 & 38,57 & 5,43 & 0,29 & 0,00 & 89,94 \\
\hline 12 & $\begin{array}{l}\text { Lecturers provide online assignments according to the } \\
\text { material and course objectives }\end{array}$ & 60,57 & 35,14 & 4,00 & 0,29 & 0,00 & 91,20 \\
\hline 13 & Lecturers provide feedback on assignments online & 26,29 & 47,43 & 20,86 & 4,00 & 1,43 & 78,63 \\
\hline \multirow[t]{2}{*}{18} & $\begin{array}{l}\text { Lecturers provide an online learning outcome } \\
\text { assessment }\end{array}$ & 41,43 & 41,14 & 13,43 & 3,43 & 0,57 & 83,89 \\
\hline & Average & 40,86 & 41,54 & 14,40 & 2,63 & 0,57 & 83,90 \\
\hline
\end{tabular}

Table 9. Recap of TCR Results per Indicator

\begin{tabular}{|l|l|l|l|}
\hline & Indicator & TCR & Description \\
\hline 1 & The ability to design learning & 96,74 & Very good \\
\hline 2 & Ability to carry out the learning process & 83,34 & Very good \\
\hline 3 & Ability to use research results to improve the quality of learning & 87,60 & Very good \\
\hline 4 & Communication with students & 78,09 & Good \\
\hline 5 & Mastering the characteristics of students & 82,23 & Very good \\
\hline 6 & Mastering learning theory and principles of educational learning & 76,17 & Good \\
\hline 7 & Ability to assess learning processes and outcomes & 83,90 & Very good \\
\hline & Total & 84,01 & Very good \\
\hline
\end{tabular}


Overall, students' perceptions of the ability of internet-based lecturers of thing or educational competence are in very good categories, it can be seen that each of the indicators studied is in the good and very good categories.

\section{CONCLUSSION}

At present, students are a generation that grows with technology, so that lecturers as educators must have the ability to use technology or known as Educational competence. Educational competence is an internet-based competency of thing as a basic skill because it has knowledge in the field of internet of things, so learning through digital human is easy to apply, such as implementing blended learning in the teaching and learning process. From the results of the study, it was concluded that lecturers at the Faculty of Economics, State University of Padang, according to students' perceptions, had very good educational competence, however, some indicators such as communication with students still needed to be improved. In conditions of online lectures, communication is a major obstacle, however, this can be overcome by using online communication facilities such as WhatsApp and forum and chat facilities on e.learning. besides mastering learning theory and educational learning principles, it can still be improved, and other indicators can be improved or maintained. With good educational competence, it is hoped that learning activities can be carried out well so that learning objectives are met and produce graduates who are in accordance with the needs of labor in the era of the industrial revolution 4.0

\section{REFERENCES}

[1] A. Y. Tosepu, Kompetensi Dosen dalam Menghadapi Era Pendidikan 4.0., LSP3I: Opini Pendidikan, 2018.

[2] E. Yulianik, "Kompetensi Dosen Menurut Mahasiswa Psikologi Universitas Brawijaya," Persona: Jurnal Psikologi Indonesia, vol. 7, no. 1, pp. 32-40, 2018.

[3[ R. Indonesia, Undang-Undang No. 14 Tahun 2005 Tentang Guru dan Dosen., 2006.

[4] M. U. Usman, Menjadi Guru Profesional, Bandung: Remaja Rosdakarya , 2006.

[5] Mustiningsih and Sunarni, "Persepsi Dosen Terhadap Program Sertifikasi Kaitannya dengan Profesionalisme," Jurnal Penelitian Kependidikan, vol. 19, no. 2, pp. 99-107, 2009.

[6] H. Darmadi, Kemampuan Dasar Mengajar, Landasan dan Konsep Implementasi, Bandung: Alfabeta, 2010.

[7] C. Melinda, "Challenges Of Lecture In Industrial Era 4.0.," Seminar Nasional
Teknopreneur Universitas Pasir Pengaraian, 2018.

[8] N. Sumaatmadja and K. Wihardit, Perspektif Global, Jakarta: Universitas Terbuka, 2009.

[9] Suhanadji, Modernisasai dan Globalisasi, Surabaya: Insan Cendekia, 2004.

[10] Sugiyono, Metode Penelitian Bisnis, Jakarta: Alfabeta, 2013.

[11] S. Arikunto, Prosedur Penelitian Suatu Pendekatan Praktik, Jakarta: Rineka Cipta, 203.

[12] D. N. Istikoma, "Pengaruh Sikap Mahasiswa Tentang Kompetensi Dosen Dalam Mengajar Dan Kedisiplinan Belajar Terhadap Prestasi Belajar Mahasiswa Pada Mata Kuliah Manajemen Keuangan Program Studi Pendidikan Akuntansi Angkatan 2012," Thesis, Surakarta, Universitas Muhammadiyah Surakarta, 2015.

[13] N. E. Inah, "Peran komunikasi dalam interaksi guru dan siswa," Al-Ta'dib, vol. 8, no. 2, pp. 150-167, 2015.

[14] I. N. Resmawa, "Pengaruh Revolusi Industri 4.0 Terhadap Kompetensi Dosen (Studi Pada Dosen Stie Yapan Surabaya)," Seminar Nasional Manajemen, Ekonomi, Akuntansi, Kediri, 2019.

[15] A. F. Ritonga, S. Wahyu and F. O. Purnomo, "Implementasi Internet of Things (IoT) untuk Meningkatkan Kompetensi Siswa SMK Jakarta 1," Risenologi: Jurnal Sains, Teknologi, Sosial, Pendidikan, dan Bahas, vol. 5, no. 1, pp. 1-8, 2020. 